УДК 342.9;347.73

DOI https://doi.org/10.32849/2663-5313/2020.7.43

Тетяна Татарова,

канд. юрид. наук, докторант

Національної академї внутрішніх справ

\title{
ФІНАНСОВИЙ І ФІСКАЛЬНИЙ КОНТРОЛЬ НА УКРАЇНСЬКИХ ЗЕМЛЯХ У СКЛАДІ РОСІЙСЬКОЇ ІМПЕРІї
}

У дослідженні йдеться про історію розвитку інституиій, які займалися сферою фінансового та фіскального контролю на украӥнських землях у складі Російської імперії. Вказується, що на початку XIX ст. реформувати управління фінансами доручили видатному державному діячеві М. Сперанському, прогресивні ідеї якого, на жаль, майже не були враховані.

Наголошується на заміні на початку XIX ст. системи державних колегій міністерствами. Після 1810 року, крім новоутвореної Державної Ради, управлінням доходами та видатками держави почали займатися різні інстаниії - Міністерство фінансів, Державне казначейство, Ревізія державних рахунків (очолював Державний контролер). Державний контролер слідкував за звітністю щодо видатків і їх відповідністю реальній картині справ.

31811 року контроль здійснювався на основі поданих документів (оригіналів), однак з 1823 року йому на зміну прийшла система звітності (розпорядники коштів лише надсилали звіти про відповідну діяльність). У 1830-х роках відбулися спроби реформування системи й розробки нових нормативних актів щодо державного контролю за доходами і видатками, однак суттєвих змін не відбулося.

З'ясовано, що у 1881 році було прийнято ииркуляр Державного контролера про введення попереднього та фактичного контролю в Російській імперії. 3 прийняттям Закону «Про Державний контроль» 1892 року було окреслено основні положення діяльності Державного контролю: самостійність і незалежність від інших міністерств, підзвітність вищому органу державного управління; здійснення ревізії доходів і видатків відокремленими місиевими органами, підпорядкованими безпосередньо иентральному контрольному органу; організованість та своєчасність проведення ревізійних дій $і$ відкритість результатів контролю.

Фундаментальне реформування, яке мало прогресивний характер (використовувався успішний досвід передових європейських держав), відбулося вже в епоху реформ Олександра II. У 1892 році був прийнятий новий Закон «Про Державний контроль», який визначав незалежність $і$ самостійність Державного контролю, чітку ієрархічну інституиійну структуру тощо. Реформаторські заходи, які розпочались на початку ХХ ст., припинилися в 1914 у зв'язку з початком Першої світової війни.

Ключові слова: контроль, ревізії, інституції, Міністерство фінансів, державний контроль.

Постановка проблеми. Система фінансового, податкового і фіскального контролю кожної держави побудована на історичних традиціях і підвалинах, які склалися у цій сфері. Побудова сучасної ефективної системи фіскального та фінансового контролю не можлива без урахування позитивного та негативного досвіду минулого, аналізу хибних підходів до реформування відповідної сфери державного управління тощо. Тому відповідна проблематика нині є досить актуальною, коли в складних фінансових умовах додаткові надходження до бюджету за рахунок ефективної системи використання коштів тощо вкрай необхідні.

Стан опрацювання. До наукового доробку проблематики історії реформування та розвитку фінансового й фіскального контролю на українських землях у складі
Російської імперії здійснили внесок дослідники О. Алексеєнко, О. Васильчук, П. ГайНижник, I. Лещух, А. Мамишев, Н. Ширкевич та інші.

Метою статті є визначення особливостей становлення і розвитку інституцій фінансового та фіскального контролю на українських землях у складі Російської імперії.

Виклад основного матеріалу. В останній третині XVIII ст. майже всі терени Наддніпрянської України опинилися під владою Російської імперії. Тут поширювалося загальноімперське право, відповідні принципи і тенденції в питаннях фінансового, податкового й фіскального контролю, яким займалися російські державні інституції. На початку XIX ст. в системі управління фінансами відбулися значні зміни, одним 3 іні- 
ціаторів яких став один із найвизначніших державних діячів того часу граф М. Сперанський.

Підготовка проекту реформи для вдосконалення фінансового контролю на початку XIX ст. доручалася саме графу М. Сперанському, за твердженням якого «управлять финансами должны три главные учреждения, которые вместе составят Министерство финансов. При этом министр финансов, государственный казначей и государственный контролер должны самостоятельно и независимо друг от друга руководить вверенными им управлениями и нести ответственность за состояние соответствующей отрасли, поддерживая между собой самую тесную связь» [2, с. 42].

При цьому контроль виконання державного бюджету М. Сперанський вважав головною функцією державного фінансового контролю. Саму ж ревізійну діяльність він пропонував поширити на всі види загальнодержавних і місцевих доходів витрат, на всі ланки державного апарату і на всіх посадових осіб, включаючи міністрів [1]. Ці та інші пропозиції мали прогресивне значення, але втілення задумів відомого реформатора звелося лише до створення Державної ради. Ця рада була позбавлена контрольних функцій, оскільки встановлювалася система особистих доповідей міністрів імператору.

За Павла I (1796-1801 рр.) основні засади започаткованої його матір'ю реформи було відмінено. Знову було введено централізацію державного управління, колегії та їх функції відновлено, обов'язки губернських казенних палат значно звужено, а їх експедиції скасовано [7].

Імператорським маніфестом Олександра I у 1802 році замість колегій створено Міністерства Військово-сухопутних сил, Військово-морських сил, закордонних справ, юстиції, народної освіти, фінансів, а також засновано Комітет Міністрів. Маніфестом 1810 року створено Державну Раду, а управління державним доходами та видатками розділено між Міністерством фінансів, Державним казначейством і Ревізією державних рахунків.

Ревізію державних рахунків очолив Державний контролер, якого було наділено повноваженнями міністра 3 правом видавати розпорядження щодо встановлення обов'язкових правил для підконтрольних установ [4]. Державний контролер мав слідкувати за правильністю оформлення доходів і відповідністю видатків, а також був зобов'язаний подавати Державній Раді висновки за кошторисами міністерств та надавати імператорській владі звіти щодо правильності та ефективності проведених витрат [8, с. 9-23].

У 1811 році під керівництвом Державного контролера засновано Головне управління ревізії державних рахунків у складі двох департаментів у цивільній і військових сферах. Контроль організовувався на документальних засадах: по оригінальних книгах і рахунках перевірялося дотримання законів та встановлених правил при надходженні та витрачанні коштів, достовірність рахунків, казенна користь тощо. Контролюючий орган видавав сумлінним (чесним) особам розрахункові свідчення, а в разі виявлення порушень - накладав стягнення на винних [7].

31823 року документальний контроль поступився своїм місцем так званій «системі генеральної звітності», за якою перевірку здійснювали в себе самі розпорядники державних коштів. Функції центрального органу державного контролю фактично обмежувалися простим аналізом рахунків департаментів міністерств і головних управлінь без перевірки приватних рахунків, оригінальних прибуткових і видаткових книг та документів.

У 1836 році Головне управління ревізій державних рахунків було реорганізовано в Головне управління державного контролю $з$ одночасним збільшенням чисельності апарату. Державний контролер А. Хитрово розробив проект Положення про державний контроль, а член Державної Ради П. Кисельов у проекті реформи контролю запропонував, щоб ревізії мали документальний характер і проводилися органом, який би не залежав від тих установ і осіб, які розпоряджалися коштами, використання яких перевіряється. Це викликало супротив, і прийнятий закон нічого не змінив ні в завданнях, ні у формах контролю. Державний фінансовий контроль фактично не здійснював ревізій звітності, оскільки не перевіряв оригінали книг і документів, а тільки розглядав генеральні звіти міністерств. Таким чином, він був позбавлений можливості робити необхідні висновки, щоб обмежити розкрадання державних коштів.

Утвердження самодержавної влади імператора Миколи I (1825-1855рр.) відбувалося насамперед шляхом зміцнення системи органів державного управління і контролю [3]. В 1836 році Головне управління ревізії державних рахунків було перейменовано у Державний контроль, діяльність якого було закріплено Положенням, що змінило його устрій і розширило права. До складу Державного контролю увійшли Рада державного контролю (під головуванням державного контролера); Товариш Державного 
контролера; контрольні департаменти з ревізії рахунків цивільного, військового, морського та залізничного відомств; канцелярія центральна бухгалтерія і архів [7].

Контрольні департаменти проводили вибіркові ревізії генеральних звітів у підпорядкованих сферах управління, під час яких аналізували вигідність різних фінансових операцій незалежно від законності їх проведення та складали річні табелі про стан організації звітності та наслідків ревізії оборотів кожного відомства.

Але контроль не зачіпав перевіркою приватні рахунки та оригінальні прибуткові й видаткові книги, тобто не проводилася повна ревізія. Крім того, кожне відомство мало власну касу для обертання коштів, а органи контролю не мали засобів, щоб їх перевірити. В той час, як Міністерство фінансів вдалося до зовнішніх і внутрішніх позик з метою покриття дефіциту бюджету, у відомствах, де було проведено ревізії кас, викривалися значні невикористані суми, що підлягали поверненню до державного казначейства [8, с. 9-23].

У статті «Про фактичний контроль у дореволюційній Росії» А. Коняєв зазначає, що після реформи Державного контролю в 60-х роках XIX ст. було надано право здійснювати фактичні ревізії лише кас Міністерства фінансів, в яких зосереджувалися всі державні доходи. Проте практика контролю показала однобічність і неповноту документальних ревізій.

Час вимагав розширення сфери застосування фактичного контролю. Ініціатор фінансово-контрольної реформи В. Татарінов (Державний контролер Росії в 18631871 роках) звернув увагу на ревізії державних доходів, стверджуючи, що «при взымании свыше 350 миллионов государственных доходов, неправильности и даже злоупотребления со стороны сборщиков гораздо более возможны и менее заметны, чем при производстве расходов» [2, с. 42.]. Він також стверджував, що «исключительно бумажная ревизия представляет одну только формальность, не удовлетворяющую ревизионных целей, а для достижения более полных и действительных результатов необходимо ввести в ревизию элемент контроля фактического» [2, с. 42].

За Олександра II (1855-1881 рр.) було започатковано пошук більш ефективних форм і методів організації державного фінансового управління та контролю. На основі вивчення досвіду Прусії, Австро-Угорщини, Бельгії та Франції генерал-контролером Департаменту цивільної звітності Державного контролю В. Татаріновим було запропоновано проект реформування системи фінансової звітності та контролю [7], яким передбачалося:

1) у фінансовій системі запровадити єдиний порядок складання кошторисів державних доходів і видатків для всіх органів управління, забезпечити виконання цих кошторисів відповідно до щорічного бюджетного закону; забезпечити «єдність каси», тобто, зосередити всі бюджетні кошти виключно в касах Міністерства фінансів [7];

2) у ревізійній системі заснувати самостійну, повністю незалежну від виконавчої влади ревізійну установу з правом проводити аналіз руху казенних капіталів і перевірки господарських операцій на підставі оригінальних документів; запровадити «попередній контроль», тобто перевірку законності видаткових наказів розпорядників кредитів перед здійсненням видаткових операцій.

Протягом 1862-1872 років пропозиції В. Татарінова були поступово запроваджені, а також розроблені загальні правила матеріальної звітності, документальної ревізії стану збереження і використання майна та елементи фактичного контролю. Іншою суттєвою ознакою контрольної реформи було утворення в 1866 році місцевих органів Державного контролю - контрольних палат, які не залежали від губернського начальства. Контрольні палати проводили документальні ревізії звітності місцевих установ на підставі бухгалтерських книг, асигновок, оригінальних документів грошових оборотів розпорядників коштів, а також проводили перевірку правильності операцій 3 матеріальними цінностями [5, с. 47].

У період царювання Олександра III (1881-1894рр.) завершився процес розпочатих раніше перетворень у сфері державного фінансового контролю [4]. У 1881 році прийнято циркуляр Державного контролера про введення попереднього та фактичного контролю в Російській імперії. 3 прийняттям Закону «Про Державний контроль» 1892 року було окреслено основні положення діяльності Державного контролю: самостійність і незалежність від інших міністерств, підзвітність вищому органу державного управління; здійснення ревізії доходів і видатків відокремленими місцевими органами, підпорядкованими безпосередньо центрального контрольному органу; організованість та своєчасність проведення ревізійних дій і відкритість результатів контролю [7].

За підсумками фактичних перевірок операцій з експлуатації залізничних шляхів у 1911-1913 роках було збережено державних коштів і матеріальних цінностей лише на 17 млн карбованців [2, с. 42]. Окрім державних залізничних шляхів, фактичний 
контроль застосувався при перевірці фінансово-господарських операцій, пов'язаних з обслуговуванням армії в мирний період, а особливо - у воєнний час. Характерно, що подальші ревізії їі звітності проводилися протягом тривалого часу.

Так, перевірки документів 3 витрат на Кримську війну (1853-1856 роки) були закінчені тільки через 30 з лишнім років у 1888 році. Під час російсько-турецької війни 1877-1878 років були створені так звані польові контролі - діючої армії Одеського військового округу і Кавказької армії (працювала загалом 161 особа), які виявили великі зловживання монопольними постачаннями продуктів. Підрядниками, які перевозили вантажі для армії; до казни було повернуто майже 11 млн карбованців [2, с. 42].

Польовий контроль діяв і під час російсько-японської війни. 31911 року фактичний контроль поширився також і на перевірку наявності та збереження грошових коштів і матеріальних цінностей в інтендантствах. За 1912-1914 роки в останніх було проведено 400 ревізій. Під час Першої світової війни (1914-1918 роки) діяльність польового контролю дещо активізувалася [2, с. 42].

Фактичний фінансовий контроль, окрім зазначених сфер, наприкінці XIX і на початку XX ст. застосовувався і щодо операцій, пов'язаних із будівництвом та експлуатацією торгових портів, спорудженням шосейних доріг, осушенням і зрошенням земель, діяльністю державних заводів тощо. Разом із тим матеріали ревізій Державного контролю 3 констатацією суттєвих порушень часто не реалізовувалися, особливо, коли йшлося про зловживання посадових осіб таких впливових відомств як військове, Міністерство внутрішніх справ і тому подібних. До того ж, виявляючи ті чи інші недоліки в різних галузях, органи зазначеного контролю не спроможні були забезпечити їх усунення, оскільки не мали відповідних прав і засобів впливу, аби змусити керівників відомств рахуватися з їх висновками.

Видатний вчений-правознавець кінця XIX ст. I. Бльох також підкреслював, що контролюючі функції в допетровській Росії, крім Великого князя (царя), належали управлінським органам - Боярській Думі, князівському «палацу», посадникам, воєводам, органам місцевого самоврядування (в особі старост і їх помічників) та іншим. І. Бльох писав: «Ліси розписувалися на ділянки, до яких визначалися лісові наглядачі (доглядачі), які обиралися в селах і поселеннях з однодворців або з відставних драгунів, солдатів чи виборних селян». Він вважав, що вищою контрольною установою на той час був Рахунковий Приказ, або Приказ Рахункових справ, обов'язком якого було відати «всієї Московської Держави прибутками і видатками, залишком по книгах за багато років». Місцевих контролюючих установ, на його думку, не існувало.

За часів правління імператора Миколи II (1894-1917 рр.) державний контроль діяв як в умовах капіталізму, так і умовах нової політичної реальності Першої російської революції [7]. У жовтні 1905 року було створено Раду Міністрів та розпочато розробку проекту перебудови державного контролю з урахуванням поділу влади на законодавчу та виконавчу. Пост Державного контролера увійшов до складу Ради Міністрів [6, с. 61-66].

Характерно, що Державний контроль був одним із найбільших відомств царської Росії. На його утримання в 19081913 роках щорічно витрачалося 10-11 млн крб. В 1911 році в його структурах нараховувалося 9 департаментів і канцелярій (центральний апарат), 59 контрольних палат, 37 установ, які контролювали будівництво і експлуатацію залізничних шляхів, а загалом функціонувало 117 підрозділів чисельністю 8398 службовців - майже стільки, скільки нині працює в органах ДКРС [2, с. 42].

Війна, яка розпочалася в 1914 році, зупинила процес реформування державного фінансового контролю до 1917 року. I все ж контроль залишався важливим інструментом державного управління. Так, за розписом Балансового зведення доходів і видатків за 1915 рік асигнування на державний контроль становили 13972 тис. крб, або 0,004\% від загального обсягу видатків бюджету [6, c. 61-66].

\section{Висновки}

Отже, на початку XIX ст. М. Сперанський, який виступив реформатором системи управління фінансами, висловив прогресивну ідею щодо об'єднання різних інституцій, які займалися питаннями фінансів, у єдине Міністерство фінансів, до якого б належали три різні центральні посадові особи - міністр, державний казначей (скарбник) і державний контролер. Вони повинні були обіймати відносно незалежні інстанції при Міністерстві фінансів, однак реформа звелася лише до створення Державної Ради без якихось суттєвих повноважень.

Після 1810 року питання державних доходів і видатків розділили між Міністерством фінансів, казначейством і Ревізєію державних рахунків. Відповідний контроль здійснювався документально. В I половині XIX ст. фінансовий контроль мав низку суттєвих недоліків, оскільки не відбувалися 
ревізії звітності видатків і доходів. Фундаментальні зміни у сфері фінансового контролю відбулися вже в епоху фундаментальних реформ Олександра II, а завершилися прогресивні зміни за Олександра III.

На початку XX ст. розпочалися нові зміни в системі контролю за фінансами, однак Перша світова війна та розпад Російської імперії зупинили ці перетворення. Загалом контроль за фінансами в Російській імперії відрізнявся значними зловживаннями з боку посадових осіб.

\section{Список використаних джерел:}

1. Алексеєнко О.В. Фінансовий контроль у Збройних Силах України : дис. канд. екон. наук: 08.00.08. К., 2009. 229 с

2. Васильчук О. Достовірно з глибини віків, або Віхи становлення державного контролю в
Російській імперії. Фінансовий контроль. 2004. № 1. С. 47-48.

3. Гай-Нижник П. Податкова політика Центральної Ради, урядів УНР, Української Держави, УРСР (1917-1930 рр.). К. : Цифра-друк, 2006. $303 \mathrm{c}$.

4. Гай-Нижник П. Фінансова політика уряду Української Держави Гетьмана Павла Скоропадського (29 квітня - 14 грудня 1918 р.). К. : Цифрадрук, 2004. 430 с.

5. Мамишев А.В. Виникнення i розвиток механізмів контролю в ретроспективі. Фінансовий контроль. 2001. № 4. С. 47.

6. Мамишев А. Трансформації органів контролю в епоху тоталітаризму / А. Мамишев // Фінансовий контроль. 2003. № 2(15). С. 61-66.

7. Соловйов С.М. Історія Росії з найдавніших часів. М. : Думка, 1988. Книга 2, Том 3.536 с.

8. Ширкевич Н.А. Финансовый контроль в CCCP. M., 1981.34 c.

Tetiana Tatarova. Financial and fiscal control in the Ukrainian lands as part of the Russian Empire

The study deals with the history of the development of institutions that dealt with the field of financial and fiscal control in the Ukrainian lands as part of the Russian Empire. It is indicated that in the early nineteenth century. to reform financial management was entrusted to the prominent statesman M. Speransky, but his progressive ideas, unfortunately, were almost not taken into account. Emphasis is placed on the replacement in the early nineteenth century. system of state boards by ministries.

After 1810, in addition to the newly formed State Council for the Management of State Revenues and Expenditures, various instances began to deal with the Ministry of Finance, the State Treasury, and the Audit of State Accounts (headed by the State Comptroller). The State Comptroller monitored the reporting of expenditures and their compliance with the real picture of cases.

From 1811, control was carried out on the basis of submitted documents (originals), but from 1823 it was replaced by a reporting system (managers only sent reports on relevant activities). In the 1830s, attempts were made to reform the system and develop new regulations on state control over revenues and expenditures, but no significant changes took place. It was found that in 1881 a circular of the State Comptroller was adopted on the introduction of preliminary and actual control in the Russian Empire.

With the adoption of the Law on State Control in 1892, the main provisions of the activity of State Control were outlined: independence and autonomy from other ministries, accountability to the highest body of public administration; audit of revenues and expenditures by separate local bodies subordinated directly to the central control body; organization and timeliness of audit actions and openness of control results.

Fundamental reform, which was progressive in nature (using the successful experience of advanced European states), took place in the era of reforms of Alexander II. In 1892, a new Law "On State Control" was adopted, which defined the independence and autonomy of State control, a clear hierarchical institutional structure and so on. Reform measures, which began in the early twentieth century, stopped in 1914 as a result of the First World War.

Key words: control, audits, institutions, Ministry of Finance, state control. 